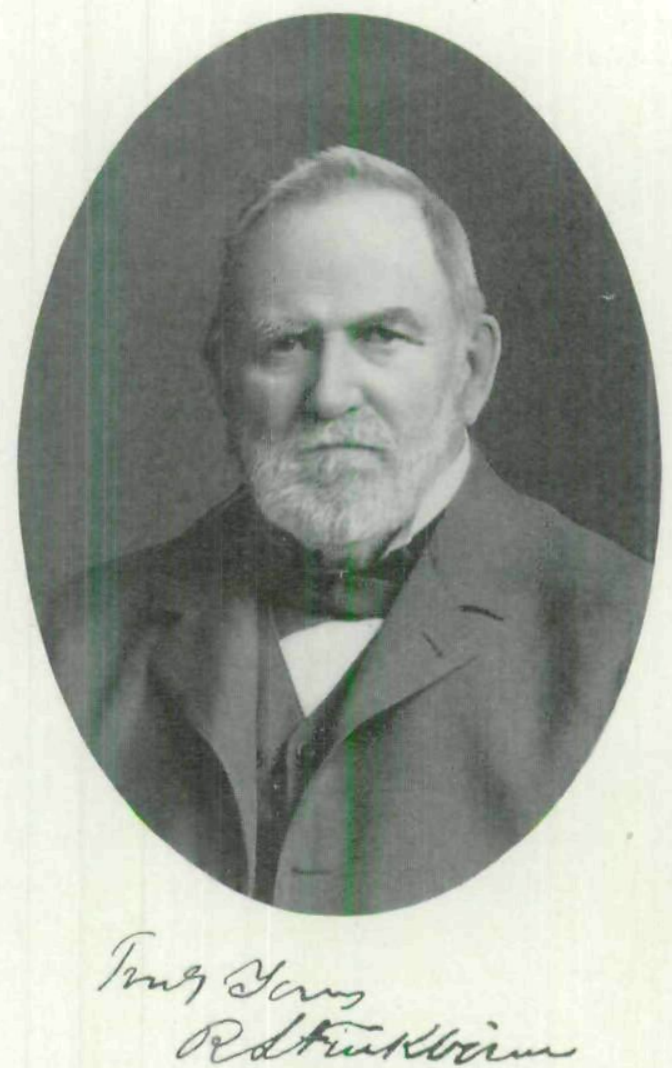

ROBERT \$, FINKBINE,

Representative from Johnson county, in the 10 th and 11 th general assemblies, $1864-{ }^{-} 66$; member of the board of commissioners in charge of the erection of the new capitol, and superintendent of construc.

tion, 1872.'84: member of the board

of public works of the city of Des Moines,

$1890-94$. 


\section{ROBERT S. FINKBINE AND HIS ASSOCIATES IN THE ERECTION OF THE IOWA CAPITOL.}

BY HON. PETER A. DEX.

I have been asked by some of my friends to write out the remarks I made at Mr. Finkbine's funeral. As there are some facts that are probably known only to myself, it will be necessary, to give a correct view of the situation and the relations of parties to each other, for me to go further into detail than was suitable on that occasion. This is my reason for bringing in the early history of the Capitol building before Mr. Finkbine's connection with it.

The General Assembly, by an act approved April 13, 1870, appointed a board of Capitol Commissioners consisting of one member from each of the congressional districts of the State, two commissioners at large-Gen. G. M. Dodge and Hon. James F. Wilson, named in the act-and the Governor, who was ex-officio president of the board. If practicable, the management of the work should be under the charge of an Iowa superintendent, and preference should be given Iowa material. Under this latter clause the board made chemical and physical tests of the building stones of the State, more thorough and complete than had been made before or have been since. As the result of these they adopted for the foundation the oolitic limestone which is found on the Iowa river in Tama county, and which seemed to have successfully withstood all the tests. Some newspaper attacked the oolitic stone, claiming that it would not resist the action of water and frost. This attack was followed by many of the newspapers of the State, and the board losing all confidence in their tests, hastened to undo their work and selected the Bear Creek stone, found in an undeveloped quarry, which had never been tested by use or otherwise. This selection satisfied everybody, and criticism ceased. The Bear Creek stone would seem to have been good, but the quarry

VoL. V. -14 . 
ran out and failed to furnish the requisite amount; the remaining stone put in the foundation by this board were obtained in Van Buren county from Rock Creek. The latter, while possibly good stone, were quarried late in the fall, and being full of water were badly shattered during the severe winter of 1871 and 1872. An investigating committee appointed by the legislature took a great deal of testimony as to the condition of the masonry in the foundations. Among them Guy Wells, an eminent engineer and contractor, after examining the walls, reported that sixty-seven stone should be removed. This unfortunate condition brought more censure upon the commission than was deserved. The Democratic papers attacked them bitterly because they were selected on purely partisan lines. The Republican papers failed to defend because the proof of a lack of either knowledge or capacity was evident.

The general assembly of 1872 retired the old board and selected four commissioners, two from each political party. The act amended and approved April 10, 1872, read as follows: "There shall be established a board of commissioners consisting of the Governor, who shall be ex-officio president of the board, John G. Foote of Des Moines county, Maturin L. Fisher of Clayton county, and R. S. Finkbine and Peter A. Dey of Johnson county." The members of this board were required to give bonds in the sum of $\$ 50,000$, and were charged with the execution of the provisions of law in respect to the erection of the capitol. Their first important duty was to inspect the work already done and remove any part thereof, that, in their judgment, did not conform to proper standards of material and workmanship. They were limited to the expenditure of $\$ 1,380,000$, which was appropriated, and were required to direct their action with a view of the completion of the building for the sum of $\$ 1,500,000$ $\$ 100,000$ to be expended in that year, and $\$ 125,000$ annually thereafter.

As I am the only one left of the men selected, I feel that 
I can speak freely, for there is no association of my entire life that I look back to with more satisfaction. John G. Foote was a merchant who had been reasonably successful in the management of his personal matters, and had practically retired at the time he came upon the board. Strictly honest and conscientious, he treated every matter that came up as he did his own affairs, and although liberal within the lines of strict justice, he never allowed sentiment or friendship to warp his judgment. He was early made chairman of the finance committee and held that position uninterruptedly until the commission was discharged by legislative enactment. So accurately were his accounts kept, (all payments going through his hands,) that the experts appointed by Gov. Wm. Larrabee, after months of examination, found a discrepancy of about two dollars, which Mr. Foote always insisted was their error, not his. He did not claim any special knowledge of mechanical construction, nor what material it was best to use under various conditions, but had an abiding faith in Mr. Finkbine's judgment. He rarely made any mistakes. I happened to be in Burlington a day or two before his death and saw him. He said, "I can live but a short time; it is best that I should go. During my illness I have thought a great deal about the capitol and my associates, and it has been a special source of satisfaction to me to know that an expenditure of nearly three million dollars was made and that there was no criticism from any source on the board. I shall die happy in the thought that the building of the capitol was an honest and wise expenditure of public money and that ours was a trust faithfully carried out."

The next member mentioned in the law was Maturin L. Fisher of Clayton county. Mr. Fisher had been president of the senate and a prominent figure in political and educational matters in the State. To the study of architecture he had devoted much time and attention. With all the classic orders he was familiar; he had studied the gothic and the renaissance architecture. He knew the quarries from which the 
stone in all the great buildings of Europe were taken, and was familiar with the analysis of all building stone prominently in use. Strictly honest in thought and deed and with the learning of the scholar, Mr. Fisher was an encyclopedia from which the board drew information. Like Mr. Foote he had to depend to a certain degree upon others for the application of what he knew to existing circumstances. His death occurred to his own and our regret before the building was sufficiently advanced to give him the full idea of what it would be. Mr. Foreman, his successor, was a lawyer, a man of considerable ability, and well fitted for the position. The difficult questions were, however, generally settled before he came on the board, so that his action did not impress itself as strongly as that of the earlier members.

Gen. Ed Wright was early elected secretary, and afterwards, assistant superintendent. He devoted himself to the duties of his position with an energy and industry that made him invaluable. He had not the mechanical or technical knowledge of Mr. Finkbine, but the fidelity with which he discharged the trust gave him the full confidence of the board. No truer man ever held a public office.

The original board in their final report made the recommendation that, in the opinion of the board, it was the best policy for the State that the board of capitol commissioners should consist of not to exceed three persons, in which both parties should be represented, who should be appointed for the time occupied in building the capitol, subject to removal by the governor or legislature, for cause only, and that they should be paid a salary that would justify them in giving their whole time to the discharge of their duties during the continuance of the work.

The general assembly had learned by experience that it was not wise to continue the construction of the capitol by a purely partisan commission, and divided the members between the two political parties, retaining the governor as chairman of the board. Messrs. Foote and Finkbine were selected by 
the Republican caucus; Mr. Fisher and myself by the Democratic caucus. My selection was due to the influence of the Hon. John P. Irish, a member of the house from Johnson county, who had been largely instrumental in securing the passage of the law and the appropriations. His brilliant addresses on the subject always filled the hall. Among the friends of the measure he was clearly foremost.

Shortly after the passage of the amended act the governor called a meeting of the board. Mr. Finkbine and I went to Des Moines on the same train. For the first time we talked over the duties imposed upon us, and discussed the best methods of managing the work. We agreed that we needed a superintendent who was more than capable. Before reaching Des Moines Mr. Finkbine said, "I would like to be superintendent of the building. Will you vote for me?" My reply was, that I would rather not answer that question now, but if insisted upon would do so. I had known Mr. Finkbine about fifteen years, but only slightly; for some reason, possibly political, I was prejudiced against him, and in addition had grave doubts as to his experience and capacity to fill the place, which we all recognized as a difficult one. In fact I knew no one whom I thought quite up to it. Mr. Fisher had this feeling in a greater degree, and expressed it to me in strong terms.

After one or two meetings it was agreed that Mr. Finkbine and I should examine the foundations already in and report what repairs were deemed necessary. This we did thoroughly and carefully, and at the end of the second day he asked what my conclusions were. To my answer that every stone must come out, he replied, "I had not gone as far as that, but perhaps you are right. Whether the capitol costs the State fifty thousand dollars more or less is a matter that will soon be forgotten, but any failure in the foundation will be a source of regret as long as the building stands."

As stated above, the commissioners were limited in the cost of the building to an expenditure of $\$ 1,500,000$. The 
plans adopted by the former board were not changed except in detail, and it is but justice to say that for the purpose designed it would even now be difficult to better them. Mr. Finkbine and I were designated a committee to determine whether the plan adopted could be built for that amount. Most of the estimates he made. We reported against any changes in the plan already adopted, but thought the building could be put under roof by using cheap material, iron columns, wooden floors, and common glass, and that, leaving off domes and ornament generally, it might be made habitable.

The next general assembly gave the commission $\$ 250$,000 in addition to the $\$ 1,500,000$ already appropriated and instructed them to put in proper material. It soon became apparent that the people of the State wanted about as good a building as could well be constructed, and for this were willing to pay what it was worth. From that time the question of cost was largely eliminated when good work entered into competition with inferior.

It was necessary to remove and replace the defective walls and to get ready for future operations. Mr. Finkbine proposed to take charge of this work, as a member of the board, at the per diem fixed in the law. This was agreed to. The removal of the old walls showed such a condition of disintegration that the board had no fears of criticism as they dumped off the grounds the refuse of what had cost the State $\$ 52,000$. In arranging and organizing his forces, and in the selection of stone and the testing cements, Mr. Finkbine showed a knowledge that belonged to an expert, and, I think, favorably impressed every member of the board. It was not long before he was elected superintendent by unanimous vote, and from that time he had no more hearty support than from the Democratic members, who gave him their fullest confidence. This was not personal friendship, but a thorough conviction that no better man could be found. Until that time it was thought that the experience in large 
buildings in the west had not been sufficient to produce competent men here. As time passed on, new questions arose, but I do not recall a single emergency that he had not planned to meet. He knew the value of iron work and iron framing quite as well as wood work and made his figures on contract material and labor that were always reliable. He was as familiar with the strains of thrust and tension as a bridge builder, and at the same time knew the cost of quarrying, dressing and laying stone, and the relative values of all cements in use. Mr. Piquenard, the architect, died during the progress of the work. Shortly afterward I called Mr. Finkbine's attention to what I feared was a miscalculation of weight on certain columns. He said, "I will figure this. You are an engineer and I a builder. The public would justly hold us responsible for any failure." It was found that additional supports were necessary. This defect was remedied, but under conditions that detract somewhat from the symmetry of the corridors.

Mr. Finkbine never attempted to belittle the acts of others, simply because opportunity offered. He was always desirous of stating their positions fully, and if he differed, he combatted their strong points fairly stated. I wish to illustrate this trait of his character, as there was at one time some feeling on the part of members of the old commission, arising from a misunderstanding of facts that, in justice to all, should be fully and finally corrected. On the $23 d$ day of November, 1871, the corner stone of the new capitol was laid with due ceremony. Addresses were made by the Hon. James F. Wilson, Governor Merrill and Hon. John A. Kasson, and a poem was read by the Hon. J. B. Grinnell. On the corner stone the names of the commissioners and the architect were carved. When, in removing the defective stone in the foundation, it became necessary to displace this, Mr. Finkbine had it carefully boxed and put it in the back end of one of the warehouses. The reason he assigned was that if it were seen about the grounds, some one would be inclined 
to make this excuse for criticising the old board. It lay there for some months. During the code session a member of the house introduced a joint resolution which directed that the names should be removed from the corner stone and that the word "Iowa" and nothing else should be carved upon it. The instructions of the legislature were carried out. This violation of good taste and the obliteration of the marks of an historic event were, by many, charged against Mr. Finkbine, as taking an advantage of the men he had succeeded. In his nature nothing of this kind could exist, and every precaution that he could adopt was taken to prevent just what was done.

He opposed the gilding of the central dome. This was largely copied from the dome of the Invalides in Paris, which was gilded. His idea was that the gilding was suggested by the bad taste and the predilection for tawdry ornament that belonged to the period of the First Empire. When, however, the gilding was determined upon, he did all in his power to have the work well done and seemed to all intents well satisfied. He never afterward criticised it.

I have said he knew accurately the value of labor and material. On one occasion an Indianapolis firm which had done some considerable work about the capitol was asked to bid upon some iron stairways amounting to a few thousand dollars. Mr. Finkbine had calculated the cost. Upon getting their bid, which was extremely high, he wrote them a note in which he stated that their figuring man was probably not at home. Shortly after he received a telegram that their expert would be in Des Moines the next day. As I had seen Mr. Finkbine's figures, I had some curiosity to compare them and found a difference of only twenty dollars.

There was one peculiarity about Mr. Finkbine that I have rarely noticed in anyone else. He had had very good early advantages, and his attainments in scholarship were unusual among mechanics of his day. He had learned by contact the mental processes of the mechanic and day laborer, and he 
had the tact to draw out from them what they knew, without seeming to be a learner. He assumed the manners and followed closely the train of thought of the men with whom he mingled and rarely failed to extract something that he might in the future use. He was a student of Miami University, and while there learned how to study, which after all is the great desideratum of institutions of learning. The popular estimate of Mr. Finkbine is, that he was a rough unhewn block, and that out of his inner consciousness he evolved the qualities that made him master of every situation in which he was placed. There never was a greater mistake. He owed more than any man in his line, I ever knew, to mental training and study. This was balanced by that broad common sense that prevented him from being a man with one idea. He was a builder, not an artist, and of the conceptions of the artist he knew little; but the model once made he could construct it in marble, stone, or metal so mechanically that it would be as imperishable as the material in which it was wrought. An example of this occurred in the north and south porticos of the capitol. The entablature between the central columns was of sandstone; the space so great that the stone was hardly able to bear its own weight, much less the mass above. Mr. Finkbine threw an arch from the columns and supported the stone by rods fastened to the entablature by lewises, all of which were so concealed that probably no one has ever questioned the strength of the material. A Chicago architect meeting this same difficulty in the old Chamber of Commerce, supported his entablature by heavy iron girders below and bolted them through, disfiguring the entire front.

In this, as in all contingencies that arose, Mr. Finkbine had thought out his plans and was ready to meet the exigencies. This ability to meet every emergency of life as it arises, is, in my judgment, true greatness.

Fifteen years have passed since the commission was disbanded. Yet Mr. Finkbine's name is as thoroughly associ- 
ated as ever in the popular mind with the building of the capitol. For the present generation it is his memorial, and may remain so longer than carved tablet would endure.

Iowa City, July 20, 1901.

TO THE REV. WILLIAM SALTER, D. D.

BY REV. OHAS, E. PERKINS.

Time lays his burden gently on the head

Of those high-minded ones who love the truth, And follow her high lead. With stately tread

Their feet press forward. Gentleness and truth

Their course inspire; sweetness and light,

Honor and faith attend their steps each day.

So Time, who loves the righteous soul, his flight

Makes manifest as softly as he may.

And though the hair be silvered, and the flesh

Pale to a finer whiteness, in the eyes

The clear light shines, while warm and fresh,

The heart, with loving fervor ever flies,

And year by year the mind grows yet more nobly wise.

Thus, thanks to God, life writes an unstained page,

And shines most glorious in the gracious youth of age.

-Congregational Iowa, May, 1901.

Beauties of Abolitionism.-When abolition was preaching against slavery it voted so that Texas should be annexed and slavery extended. It pretended to be in favor of the abolition of the black laws in Ohio, and voted so as to be sure that the friends of these same black laws might get into power. Its political consistency is very excruciating. It punishes where it pretends to heal-tortures where it proposes to soothe. It has a most lively sympathy for the suffering slave and permits the poor to die at its own door. It has a holy horror of wrong, and is quite contented with the social evils in its path. Amiable abolitionism! Verily thou art a contradiction.-Bloomington Herald, October 30, 1846. 
Copyright of Annals of Iowa is the property of State of Iowa, by \& through the State Historical Society of Iowa and its content may not be copied or emailed to multiple sites or posted to a listserv without the copyright holder's express written permission. However, users may print, download, or email articles for individual use. 